\title{
Development of Thematic-based Motion and Song Learning Videos to Stimulate Work: Art of Kindergarten Teacher's Ability
}

\author{
Retno Tri Wulandari ${ }^{1, *}$, Nur Anisa ${ }^{2}$ \\ ${ }^{1}$ Faculty of Educational Science, Universitas Negeri Malang, Indonesia \\ ${ }^{2}$ Faculty of Education, Universitas Negeri Malang, Indonesia
}

Received August 23, 2019; Revised November 24, 2019; Accepted December 3, 2019

Copyright@2019 by authors, all rights reserved. Authors agree that this article remains permanently open access under the terms of the Creative Commons Attribution License 4.0 International License

\begin{abstract}
The purpose of this development research is to make an early childhood-based song and motion-based learning videos to stimulate the learning skills of senior kindergarten teachers. The research method uses research and development, Borg and Gall models, with 10 development steps being adapted into 8 steps namely; 1) Preliminary Research and Information Collection, 2) Planning, 3) Initial Product Development Format, 4) Early Trial, 5) Product Revision, 6) Initial Trial, 7) Product Revision, 8) Field Test. The research instrument used was a questionnaire which was a validation sheet from media experts and senior learning experts and research respondents, consisting of 30 kindergarten teachers throughout Malang City. The collected data will be processed descriptively quantitatively presented in the form of a percentage, and qualitative from suggestions to product development. The results of this study are learning media products consisting of $1 \mathrm{CD}$ product development movement and song and a teacher's guidebook. These media have also been proven to be valid, practical and effective for early childhood learning and enhancing the learning ability of Kindergarten teachers.
\end{abstract}

Keywords Thematic-based Movements and Songs, Dance Skills, Kindergarten Teachers

\section{Introduction}

Art is one aspect of early childhood development that needs to be maximized. The aesthetic experience obtained by early childhood through the process of learning dancing can help children to be sensitive to the value of beauty, sensitive to space and sensitive to the surrounding environment. So it can be concluded that actually by learning art children can be stimulated by all aspects of growth and development, because art is one of the media of education (education through art).

In practice learning dancing in PAUD also requires teachers to be creative and have a lot of provisions in developing teaching materials. Requiring a lot of references both from print or from the media provided to add insight. Effective learning media are also needed to maximize the learning process in the classroom. The fact is that dance in early childhood at PAUD is still not optimal, which is evidenced by the results of the needed analysis research conducted by previous researcher Wulandari (2017) that teacher competence in implementing learning for children of age is still not as expected, some factors that cause, among others, a lack of mastery of the field of development art of early childhood dancing.. The teacher does not have enough background and knowledge about the art of children dancing, lack of ability and creativity in developing the material of motion and music accompaniment of children's dance, as well as lack of skills in delivering dance material for early childhood. The recommendations from the results of the study state that PAUD teachers, especially Kindergarten in the Kindergarten of Malang City, need learning media for dance that can enrich the development of learning materials.

The use of instructional media as a tool in the teaching and learning process, especially in PAUD can facilitate the task of teachers in delivering messages from learning material, giving rise to children's learning motivation, in this case related to the teacher's professional competence in carrying out their duties. It is also related to the ability of teachers to choose effective media and material to use. The use of learning media in relation to teacher professional competence in this study is intended to mastery and development of material, scientific concepts that support the subjects taught, as well as utilize information technology in the form of thematic and song-based learning videos for early childhood. 
In connection with the material of the process of working dance for early childhood, it should be directed more towards thematic-based dance education, due to theme-based early childhood learning. From the themes in the PAUD learning, it can be used as an idea in creating innovative works to develop the artistic abilities of early childhood. The excavation of 11 themes in early childhood learning is used as a basis for exploration of motion and all supporting elements in dance works. The results of the exploration are manifested in the form of educational dance which is more directed at the ability of children to develop their potential. In the end, the form of thematic-based dance works produced can be used as learning material that can be utilized in any learning in the school and can be combined with other material with the same theme in one learning day. Kindergarten teachers throughout Malang City are expected to have skills in working on thematic-based dance.

In order to make kindergarten teachers be more motivated to learn and add insight into art learning, and to further improve early childhood movement and song skills, the researchers offered the development of thematic-based motion and song learning videos for early childhood using teaching aids in the form of visual information in CD form. This development research is a follow up from previous research on analyzing the competency needs of early childhood teachers in dance learning.

\section{Literature Review}

\subsection{Thematic-based Motion and Song Learning}

Motion and Song are part of the form of dance material that can be given to early childhood. Motion and song learning can be interpreted as a set of materials or learning materials that are planned and carried out in the form of motion and song as a basis for stimulating the development of all aspects of early childhood abilities. In accordance with Sandor's opinion (1975: 4) learning through motion and song performed while playing will help children to develop their intelligence not only in aspects of art development, language and physical course but also in children's emotional and cognitive development. According to Wulandari (2017) that through the application of motion and songs for early childhood through the BCCT method can improve their creativity.

Setyawati (2012) says that motion and song are examples of material for children of play age that are adapted to the children's developmental abilities. Motion is created as an expression of the song, so the motion must be made in half of the overall proportion of the display, and the song is also displayed with the correct vocal technique as half a part of the overall proportion. So the processing of motion does not prioritize high aesthetics, because it will damage the concentration of the child on the song, on the contrary the song must also be trained with correct tone, rhythm and dynamics techniques, but also should not be too dominant to be strengthened so that the child is barely moving. In essence the motion and song must be made proportionally, so that it is balanced between motion and song. The form of his activities is children singing while dancing.

Based on this opinion, it can be concluded that the activity in motion and song is understood as a form of motion performed by the child adjusting to the poetry and rhythm in the song. The terms of the motion material and songs given to early childhood are simple forms of motion, the tempo / rhythm of movement is not too fast, the theme adapts to the development of the child, the atmosphere is happy and agile. In the implementation of motion and song learning adapted to the basic motor skills of early childhood.

According to Wulandari (2014: 147-148), learning art contains two aspects of competence, namely skills and creativity. Skills competencies focus more on children's exploration experiences to train sensory and motor skills, not to make children be proficient or expert. Creativity competence includes the cognitive, affective, and psychomotor domains that can be seen from products or works and processes in creative self-busyness. Psychomotor skills emphasize the formation of children's awareness to move spontaneously, in moves demanded to be smooth, orderly, flexible and expressive without any burden in performing dance moves.

According to Duhun (in Hanifah, 2012) "dancing is the encouragement of the human soul since children express themselves when they hear or feel the vibration of a rhythm within themselves". The instinct will disappear if it is not fertilized early. In fact, this condition is experienced by most humans. In order for these natural instincts not to disappear, the teacher must be able to facilitate children to dance early so that they want to learn and get to know the traditional arts. According to Wulandari (2014: 157-158), the stages in the learning process of song or dance movements in early childhood are described as follows: (1) Adjusting the psychological condition of the child, then choosing the theme of song movements (2) Choosing the song's moving material with a theme the environment or the theme that is close to the life of the child, (3) Selecting movements that have a low level of difficulty so that the child is able to follow, (4) Selecting a dynamic path medium, soft and fast because dynamic variations will train variations in children's emotions, 5) Making the floor pattern of motion of the song as simple as possible, (6) Educators should master the song movement material before teaching, (7) Giving the forms of movement gradually starting with one type of movement pattern not at once, because one variety of motion requires a motor coordination that requires time to train it. (8) Making alternations in the form of stories that are relevant to the theme of the song / dance movement that will be taught, (9) If the material of the range of motion has been achieved, it is necessary to do repetitions of motion so that the shape becomes optimal. (10) The Educator must be good at 
dividing the song's moving material in several meetings that need to be considered as the physical and psychological condition of the child. In principle, do not force the child if the child's condition is no longer possible.

Based on the description of the theory it can be concluded that learning motion and song by following the steps that have been systematically arranged will facilitate learning, while at the same time generating more effective and maximum learning. Therefore it is necessary to have an activity that can train and provide references to early childhood educators in providing stimulation to children through motion and song, as well as in developing material activities. Theme-based song and song learning mean that extracting ideas in the work of motion and songs for early childhood is adjusted to the themes used in early childhood learning. These themes are used as the basis for processing material movements, so that the motion and song material can later also be used as one of the materials that can be combined with other fields of material development in early childhood. The results of the training from community service activities (Wulandari \& Kustiawan, 2018) that works of art use themes in early childhood learning can be maximized to achieve child development, and the results can be directly practiced by teachers in their schools.

Based on the K13 theme development guidelines there are 8 themes that can be used or further developed by the teacher, namely: myself, environment, animals, plants, vehicles, the universe, my country, and my culture. These themes can be further developed with sub-themes and sub-sub-themes according to the needs of each class / institution, but in developing this video learning product the themes used are limited to the themes of animals, my homeland, profession, myself, the universe.

\subsection{Teacher's Competence in Teaching Art for Early Childhood}

The ability to realize the professionalism of PAUD teachers is a response to the increasing demands of the social environment of the people who want an increase in the quality of education services, including early childhood. The formulation of four teacher competencies which are the general and basic framework which is further elaborated in the competence of PAUD teachers can be used as an indicator to assess the extent to which PAUD teachers have the ability to understand and actualize the dimensions of their abilities. This is in accordance with the opinion of Pantic (2010) which states that there are 4 components that underlie teacher competence, namely: 1) understanding the values of child development; 2) understanding of the education system and contribution to its development; 3) knowledge of students, pedagogy, and curriculum; and 4) self-evaluation and professional development. Whereas Ilanlou \& Zand (2003) explained that professional teachers must have 3 competencies, namely: cognitive, emotional and practical competencies. Cognitive competence is related to teacher cognition, student cognition, and cognition of the teaching-learning process. Emotional competence is a competency that is based on interests, values, and attitudes. Practical competence refers to the competence of teachers in relation to students, classrooms, schools and society. This development product aims to improve the practical competence of PAUD teachers.

The actualization of this competency will be the main standard for assessing the extent and depth of PAUD teacher professionalism. In this case it also relates to the competence of PAUD teachers in teaching dance for early childhood. In the appendix of Minister of National Education Regulation Number 16 of 2007, on 4 May 2007, the standard academic qualifications and PAUD teacher competencies are fully developed from the four main competencies, namely pedagogic, personality, social and professional competencies, which are integrated in PAUD teacher performance in teaching all fields, in this case also in dance learning. Specifically related to dance learning, a teacher is required to have teacher competencies which include:

Table 1. Teacher's Competencies of Dance in Early Childhood Education

\begin{tabular}{|c|c|c|c|}
\hline Competence & & Competency Indicators for Early Childhood Teachers & $\begin{array}{c}\text { Teacher's Competency Indicators in Dance } \\
\text { Learning }\end{array}$ \\
\hline $\begin{array}{l}\text { Pedagogic } \\
\text { Competence }\end{array}$ & 1. & Using learning technology & $\begin{array}{l}\text { The selection of dance art learning media for } \\
\text { early childhood and the use of media in the } \\
\text { form of videos, images, or dance property, etc. }\end{array}$ \\
\hline \multirow[t]{3}{*}{$\begin{array}{l}\text { Professional } \\
\text { Competence }\end{array}$} & 2. & $\begin{array}{l}\text { Mastering the basic concepts of mathematics, science, } \\
\text { language, social knowledge, religion, art, physical education, } \\
\text { health and nutrition as a means of development for each scope } \\
\text { of development }\end{array}$ & $\begin{array}{l}\text { Mastering the basic concepts of art knowledge } \\
\text { as a means of developing each development } \\
\text { environment, } \\
\text { Culture-based material development for early } \\
\text { childhood }\end{array}$ \\
\hline & 3. & $\begin{array}{l}\text { Understanding the abilities of children in each scope of } \\
\text { development }\end{array}$ & $\begin{array}{l}\text { Understanding the level of mastery of dance } \\
\text { material for early childhood }\end{array}$ \\
\hline & 4. & $\begin{array}{l}\text { Processing the material scope of development creatively in } \\
\text { accordance with the level of development of students }\end{array}$ & $\begin{array}{l}\text { Having skills in teaching dance for early } \\
\text { childhood }\end{array}$ \\
\hline
\end{tabular}

(adaptation of the Minister of National Education Regulation Number 16 of 2007 dated May 4, 2007 concerning PAUD Teacher Competence) 
In this study more specifically to the competence of PAUD teachers in teaching the field of dance to children, in relation to the development of learning materials that can be stimulated through increasing the ability to create art. One of the efforts taken is through the use of motion media CDs and songs as a reference for the development of material and the teacher's ability to work. In accordance with the results of Wulan and Kustiawan's research (2018) that the problem of learning dance in the field is the lack of fulfillment of pedagogical, personality and professional competencies possessed by kindergarten teachers in Malang City in dance art learning, while efforts to improve teacher competence in art learning dance are by increasing the knowledge and skills of teachers in learning the art of early childhood dance through the provision of dance learning videos for early childhood.

Therefore this study seeks to provide an alternative example of the form of development of thematic-based motion and song material that is in accordance with the PAUD learning curriculum.

\subsection{Thematic-based Motion and Song Videos Stimulate Kindergarten Teachers' Artwork Ability}

The ability of teachers to work in art still requires a lot of references, and providing a lot of media or reference sources is very helpful for teachers in stimulating their abilities. This is consistent with the results of a previous study by Wulandari and Kustiawan (2008) which stated that to improve the art competencies of Kindergarten teachers in Malang City, requires the addition of frequency of training or workshops, and the need to provide dance learning videos for early childhood. This is also confirmed by the results of community service, namely in the form of training in the creation of thematic-based dance given to early childhood education teachers, showing that the ability of teachers to work can be improved by providing direct practice experience and providing appropriate examples or form of movement with themes in art learning. The creation process that is experienced by the teacher reaches the stage of appearance and reporting of work, so that the teacher understands each step of exploration and artistic creation that is adapted for early childhood (Kustiawan \& Wulandari, 2008).

\section{Methodology / Materials}

This study uses a research and development model (Research and Development) designed by Borg \& Gall (in Setyosari, 2010: 204) to produce products in the form of thematic-based learning videos and songs for early childhood. The Borg \& Gall model has 10 steps, but the researchers modified it into 7 steps, because it was adjusted to the conditions encountered in the development process, so that the development step ended in product validation. The steps are described as follows: (1) Conducting research and gathering information (literature review, class observations, preparation of the main problem report). Conducting a needed analysis, which researchers have done in 2017 research on the need to use learning media to improve the competence of PAUD teachers in learning motion and song, (2) Planning in the form of drafting products for motion and song-based song learning videos for early childhood, ( 3 ) Developing initial product forms in the form of thematic motion and song learning videos for early childhood, (4) Expert testing of products carried out by early childhood art learning experts, learning media experts on developed media products, (5) Initial product revisions based on input and suggestions from experts, (6) Obtaining validity data by distributing questionnaires to 5 teachers from PAUD institutions in Kedungkandang Subdistrict, (7) Conducting revisions based on the suggestions presented, (8) Field testing by conducting FGD inviting 30 PAUD teachers -Kota Malang to obtain data on the level of validity and the media developed and implemented $\mathrm{n}$ revisions based on suggestions from the FGD results.

Product testing was carried out by 2 art learning material experts, 2 learning media experts and respondent tests to obtain validity level data and product development. Field testing was conducted by holding a Forum Group Discussion (FGD) which invited 30 kindergarten teachers throughout Malang City. The research instrument used was a questionnaire. Questionnaires were used to collect quantitative data, namely the assessment of responses from learning media experts and early childhood art learning experts, as well as respondents from the study. Qualitative data in the form of expert advice on product design, FGD results with respondents. The indicators used for validation in media experts include: (1) The suitability of the media to stimulate the ability of TK teachers to work, (2) Quality and media display. The indicators used for the validation of material experts include: (1) The ability of the media to embed concepts and deliver material based on the themes of early childhood learning, (2) Conformity of material for early childhood, (3) Conformity of material with the aim of stimulating abilities working kindergarten teacher. The indicators used to obtain product validation data from respondents include: (1) The quality of the media in terms of video, material, and packaging, (2) The influence of the media to stimulate the teacher's work ability. Data analysis techniques used in this research and development are qualitative and quantitative data processing techniques in the form of percentages. Qualitative data is in the form of advice and input from experts who are used to make revisions to product design, as well as from product user respondents, namely kindergarten teachers. Quantitative data in the form of a percentage of the results of data collection on small group test data trial of large groups and assessment guidelines. Data analysis for effectiveness uses the t test, and looks at the effectiveness of motion videos and songs to stimulate the skills of kindergarten teachers. 


\section{Results and Findings}

\subsection{Product Description Development Results}

Development Products are in the form of early childhood-based motion learning and song-based videos and teacher instructional guidebooks, which aim to stimulate the ability to work in kindergarten teacher art and add references in an effort to improve the competence of early childhood art teachers. Motion and song learning videos use five themes that exist in Kindergarten learning, including: animal themes, professions, myself, the universe, my homeland. This learning video consists of $1 \mathrm{CD}$ that has been packaged as attractive as possible, containing the moving material of the song based on predetermined themes and a motion tutorial that is described in more detail. Learning videos for the development of thematic motion and early childhood songs is based on the title; (1) My Geese, (2) Police, (3) This Is My Body, (4) Unlimited Goose, (5) Indonesian Children Cheerful.

The product is equipped with a teacher instructional guidebook to make it easier for teachers to apply motion and song material in more detailed stages. The guidebook contains song poetry material, song notation, and movement descriptions that have been completed with motion counts, motion descriptions and motion pictures.

\subsection{Result and Analysis}

This media has passed from 2 media expert, 2 material expert, and 35 Kindergarten Teacher Respondents in Malang. These are theresults of level validity of result:

Table 2. Analysis of Level Media Validity

\begin{tabular}{cccc}
\hline Subject & Percentage & Notes & Meaning \\
\hline $\begin{array}{c}\text { Materialialistic } \\
\text { Expert }\end{array}$ & $88 \%$ & $\begin{array}{c}\text { Extremely } \\
\text { Validity }\end{array}$ & $\begin{array}{c}\text { Used without } \\
\text { minor revision }\end{array}$ \\
\hline Media Expert & $83 \%$ & $\begin{array}{c}\text { Sufficent } \\
\text { Validity }\end{array}$ & $\begin{array}{c}\text { Used with minor } \\
\text { revision }\end{array}$ \\
\hline $\begin{array}{c}5 \text { Teachers } \\
\text { (Small Group } \\
\text { Experiment) }\end{array}$ & $98 \%$ & $\begin{array}{c}\text { Extremely } \\
\text { Validity }\end{array}$ & $\begin{array}{c}\text { Used without } \\
\text { revision }\end{array}$ \\
\hline $\begin{array}{c}\text { 30 Teachers } \\
\text { (Large Group } \\
\text { Experiment) }\end{array}$ & $87,3 \%$ & $\begin{array}{c}\text { Extremely } \\
\text { Validity }\end{array}$ & $\begin{array}{c}\text { Used without } \\
\text { revision }\end{array}$ \\
\hline AVERAGE & $\mathbf{9 0 . 1 \%}$ & $\begin{array}{c}\text { Extremely } \\
\text { Validity }\end{array}$ & $\begin{array}{c}\text { Used without } \\
\text { revision }\end{array}$ \\
\hline
\end{tabular}

The advice given from the results of the validation test is the addition of detailed images in the teacher's instructional guidebook in addition to the description of the motion that has been provided, displaying all the themes on the cover of the development video, thus representing the contents of the material. Multiply product development so that it can be used massively by kindergarten teachers, as well as training to utilize development products.

The effectiveness test of the media in the form of motion learning videos and thematic-based songs to stimulate the art work ability of kindergarten teachers, was carried out on the data from the pretest and posttest results of 30 kindergarten teachers in all the cities of Malang obtained the results described in the following table;

Table 3. Pretest and Posttest Observation Results

\begin{tabular}{|c|c|c|c|c|c|c|}
\hline & \multicolumn{3}{|c|}{ Assessed Aspects (Score) } & \multirow{2}{*}{ Total } \\
\cline { 2 - 7 } & $\begin{array}{c}\text { Understanding the work } \\
\text { concept of the motion art } \\
\text { of early childhood }\end{array}$ & $\begin{array}{c}\text { Practical skills in } \\
\text { making work } \\
\text { techniques }\end{array}$ & $\begin{array}{c}\text { Motion form } \\
\text { creativity }\end{array}$ & $\begin{array}{c}\text { Original } \\
\text { work }\end{array}$ & $\begin{array}{c}\text { Educational } \\
\text { work value }\end{array}$ & $\begin{array}{c}\text { score } \\
\text { Pretest Average }\end{array}$ \\
\hline $\begin{array}{c}\text { Posttest } \\
\text { Average }\end{array}$ & 3,04 & 2,73 & 3,43 & 3,65 & 2,86 & 15,73 \\
\hline
\end{tabular}


Based on table 3, it shows that the results of the score on the ability to work in kindergarten teacher dance, which includes aspects of understanding the concept of working early childhood motion art, practical skills making techniques, creativity in motion, original work, and educational values of works that produced before getting treatment, obtained an average yield of 15.73, and after getting the treatment of 18.30 shows a positive difference. Then tested the hypothesis by comparing the results of the pretest and posttest with the correlation formula as follows;

Table 4. Results of the Pretest and Posttest Hypotheses

\begin{tabular}{|c|c|c|c|c|c|c|c|}
\hline & $\mathbf{X}_{\mathbf{1}}$ & $\mathbf{Y}_{\mathbf{1}}$ & $\begin{array}{c}\left(\mathbf{X}_{\mathbf{1}}-\overline{\mathbf{X}}\right) \\
(\mathbf{x})\end{array}$ & $\begin{array}{c}\left(\mathbf{Y}_{1}-\overline{\mathbf{Y}}\right) \\
(\mathbf{y})\end{array}$ & $\left.\mathbf{( x}^{2}\right)$ & $\left.\mathbf{( y}^{2}\right)$ & $(\mathbf{x y})$ \\
\hline Total & 362 & 421 & 0,09 & 0,02 & 103,33 & 31,99 & 43,07 \\
\hline Average & 15,73 & 18,30 & & & 4,50 & 1,40 & 1,89 \\
\hline
\end{tabular}

Based on the calculation data using the t test in table.4 data analysis results of the pretest and posttest, obtained the results of $t$ count $=5.19$ with a significance level of $5 \%$ (for education) that is 0.413 , r value of 0.75 , and $t$ table value of 2 , 08. Therefore, getting the value of $t$ count $>t$ table which means $\mathrm{HO}$ is rejected and $\mathrm{Ha}$ is accepted. Then it can be concluded that the motion video and thematic-based songs proved effective to improve the results of the kindergarten art teacher's work. Thematically based motion and song videos can thus be declared valid and effective to stimulate the ability to create art in kindergarten teachers.

\subsection{Revised Product Review}

This research and development has produced a thematic-based learning video with a learning theme for early childhood. Motion learning videos and thematic-based songs in it contain material in the form of videos, sound of motion material and songs along with detailed motion tutorials. This is in accordance with the opinion of Winarno (2009: 8) about the media in the form of learning videos.

These media have been adjusted to the needs of the 2013 curriculum learning, with a theme limited to 5 themes, namely the theme of animals, my homeland, profession, myself, and the universe, so that the material can be integrated with everyday learning. Hopefully these media can be utilized maximally in learning, so that motion and song material do not only function as supplementary material for extracurricular activities or annual incidental activities.

Learning of motion and song by following the steps that have been systematically arranged will facilitate learning and can produce more effective and maximum learning (Wulan, 2014). Based on this theory, there are needs to be an effort that can train and provide references for early childhood educators in providing stimulation to children through motion and song, as well as in developing material activities. Therefore the development of thematic-based motion and song learning videos was carried out to provide a reference for material motion development and this thematic-based song is carried out to provide a reference for the development of motion material and stimulate the ability to work in kindergarten teacher's arts.

The development of research is a solution of teacher problems in the field about the need for a lack of reference to art learning media for early childhood, in other words as a form of follow-up from previous studies, Wulan (2017) that the problem of dance learning in the field didn't fulfill pedagogical competence, the personality and professionalism of kindergarten teachers throughout Malang in learning dance, while the efforts that should be made to improve teacher competency in dance learning are to increase the knowledge and skills of teachers in the art learning of early childhood dance through the provision of dance learning videos for children early age.

The product of development research is an effort to stimulate an increase in the ability to create art for kindergarten teachers as well as an element of teacher professional competence in the field of dance. This is included in the pedagogical standard of competence, namely the ability to choose and utilize dance learning media in the form of videos and cultural-based art material development for early childhood as well as skills in teaching dance for early childhood, according to the results of previous research by Wulan (2017) and Regulation of the Minister of National Education Number 16 of 2007 dated May 4, 2007 concerning PAUD Teacher Competence.

The video learning media also fulfill the criteria: (1) valid, which means that it matches the goals of early childhood learning, and field needs, namely the need for references or media to stimulate the kindergarten teacher's artistic ability to work, (2) practical means that the media is familiar and capable of developing a learning atmosphere that is fun for students and teachers and easy to use by teachers (3) effective means that the media are able to embed concepts that are appropriate to the theme of early childhood learning, and able to increase teachers' knowledge or insights about the appropriate material for motion art and songs with early childhood. This criterion is in accordance with the utilization theory, principles and values of media use expressed by Zaman (2014) and Sadiman (2012). Effective use of media to clarify the presentation of learning messages is to be conveyed to early childhood.

The video learning media have been validated by materialistic experts, media experts. Data processed from the validation questionnaire of material and media experts stated that this product is feasible to use but requires a small revision.

After going through the process mentioned, it was found that motion products and songs for thematic-based on learning were simple and in accordance with the characteristics of early childhood. The theory of the motion characteristics of kindergarten children that the characteristics of the age of kindergarten are more simple, meaningful and themed, the movement of children mimics 
the daily movements of parents and also those around them, and children also mimic the movements of animals (Kamtini and Tanjung, 2005). In addition, song lyrics on the 5 songs in the learning video are easily memorized and sung by children. As expressed by AT. Mahmud, (in Rachmawati \& Kurniati, 2010: 23) music is a creative activity. A creative child will show curiosity, willingness to try, and broad imagination.

The results of experts' review of the product review development design of motion and thematic-based songs are as follows: adjusting the appearance of the cover with 5 themes which are the basis for the development of motion and song and the addition of detailed motion pictures in the guidebook. The advantages of learning video media are as follows: (1) The media is thematic and in accordance with the K13 curriculum so that it is needed in the present, (2) This media is very valid and can be easily used, (3) This media is practical and facilitates the teacher in developing learning materials, (4) Learning of art and song material can be implemented in an integrated manner with other learning materials, (4) Media CDs are equipped with tutorials on the stages of material giving details for each movement, (5) These media are interesting and able to increase teacher motivation creating art, (6) These media are durable and can be used many times.

\section{Conclusions}

Theme-based motion and song development research can motivate and stimulate kindergarten teachers to create art in an effort to improve competence. Motion-based learning videos and theme-based songs can also be used as a reference for teachers to add insight into art learning, especially motion and song material adapted to the overall learning theme. This statement is supported by the results of the recommendations in the FGD that the teachers were enthusiastic to get training activities as an indirect form of the results of this research development. In addition, from the results of the effectiveness testing of product development, it has proven to be effective in stimulating the ability of the Kindergarten teachers to create art.

As for some suggestions given by researchers to related parties, including: (1) For teachers, researchers suggest that teachers use these media for embeding the concept according to the 5 themes that underlie the development of learning videos, because these media are proven to be valid, practical and effective for early childhood learning and enhance the ability to create art for kindergarten teachers. Teachers are also advised to be creative in creating motion and song material by studying references that have been provided in development products, (2) For other researchers, the researcher suggests that other relevant research such as interactive development results be based on existing weaknesses and opportunities to do continued research such as measuring the effect of the implementation of the media on children's skills, (3) For the Research Service, the researcher suggested that in the future more intensive training in motion and song material should be developed as a follow-up to the results of the research.

\section{REFERENCES}

[1] Ilanlou, Maryam \& Zand, Maryam. (2011). Professional Competencies of Teachers and the Qualitative Evaluation. Procedia - Social and Behavioral Sciences. 29 (Pages 1143 1150)

[2] Kamtini dan Tanjung. (2015). Bermain Melalui Gerak dan Lagu di Taman Kanak-Kanak. Jakarta: Departemen Pendidikan Nasional, Direktorat Jenderal Pendidikan Tinggi, Direktorat Pembinaan Pendidikan Tenaga Kependidikan Dan Ketenagaan Perguruan Tinggi.

[3] Patnic, Natasa. (2010). Teacher Competencies as a Basis For Teacher Education. Teaching and Teacher Education An International Journal of Research and Studies. 26(3) Pages 694-703.

[4] Peraturan Menteri Pendidikan Nasional Nomor 16 Tahun 2007 Tanggal 4 Mei 2007 tentang Kompetensi Guru PAUD

[5] Rachmawati, Yeni dan Euis Kurniati. (2010). Strategi Pengembangan Kreativitas Pada Anak Usia Taman Kanak-Kanak. Jakarta : Kencana Prenada Media Group.

[6] Sadiman, A.S., Rahardjo R., Haryono A., Rahardjito. 2012. Media Pendidikan Pengertian, Pengembangan, dan Pemanfaatannya. Jakarta: PT Grafindo Persada.

[7] Setyawati, Sri. 2012. Pendidikan Seni Tari dan Koreografi untuk Anak Usia Dini (Edisi Revisi). Surabaya: Unesa University Press.

[8] Undang-Undang Republik Indonesia Nomor 14 Tahun 2005 Tentang Guru dan DosenWidianawati, N. (2011). Pengaruh Pembelajaran Gerak dan Lagu dalam Meningkatkan Kecerdasan Musikal dan Kecerdasan Kinestetika Anak Usia Dini. Inovete.(2), 220-228.

[9] Wulandari, Retno Tri. 2014. Pembelajaran Olah Gerak dan Tari sebagai Sarana Ekspresi dan Apresiasi Seni Bagi Anak Usia Dini. Artikel Proseding

[10] Garvis, S., \& Pendergast, D. (Ed.). (2016). Asia-Pacific Perspectives on Teacher Self-Efficacy. Diambil dari https://www.springer.com/gp/book/9789463005210

[11] Kustiawan, U., \& Wulandari, R. T. (t.t.). PENERAPAN TEKNIK BERKARYA SENI UNTUK PENGEMBANGAN KEPROFESIAN BERKELANJUTAN GURU TK KOTA MALANG. 9.

[12] Wulandari, R. T. (2017). The Implementation of Song and Motion Learning Through the Model of Beyond Center Circles Time(Bcct) to Improve Early Childhood Creativity. Proceedings of the 9th International Conference for Science Educators and Teachers (ICSET 2017). Dipresentasikan pada 9th International Conference for Science Educators and Teachers (ICSET 2017), Semarang, Indonesia. https://doi.org/10.2991/icset-17.2017.2

[13] Wulandari, R. T., \& Kustiawan, U. (2018). Evaluation Study 
34 Development of Thematic-based Motion and Song Learning Videos to Stimulate Work - Art of Kindergarten Teacher's Ability

of Early Formal Education Teacher Competence in Early Childhood Learning Dance at Kindergartens in Malang, Indonesia. Research on Education and Media, 10(1), 3-8. https://doi.org/10.1515/rem-2018-0002

[14] Wulandari, R. T., Kustiawan, U., \& Astuti, W. (2018). PELATIHAN BERKARYA SENI TARI AUD BERBASIS TEMATIK UNTUK PENGEMBANGAN PROFESI GURU TAMAN KANAK KANAK. 6. 